\title{
Antigen-driven focal inflammatory death of malaria liver stages
}

\author{
Ganchimeg Bayarsaikhan ${ }^{1,2}$, Masoud Akbari ${ }^{2}$, Katsuyuki Yui ${ }^{2}$ and Rogerio Amino ${ }^{\text {* }}$ \\ Unité de Biologie et Génétique du Paludisme, Département Parasites et Insectes Vecteurs, Institut Pasteur, Paris, France \\ ${ }^{2}$ Division of Immunology, Department of Molecular Microbiology and Immunology, Graduate School of Biomedical Sciences, Nagasaki University, Nagasaki, Japan
}

\section{Edited by:}

Ute Frevert, New York University

School of Medicine, USA

Reviewed by:

Ute Frevert, New York University

School of Medicine, USA

Ann-Kristin Mueller, University

Hospital Heidelberg, Germany

Volker T. Heussler, University of

Bern, Switzerland

*Correspondence:

Rogerio Amino, Unité de Biologie et

Génétique du Paludisme,

Département Parasites et Insectes

Vecteurs, Institut Pasteur, 28 rue

du Docteur Roux, 75724 Paris

Cedex 15, France

e-mail: roti@pasteur.fr
Multiple immunizations using live irradiated sporozoites, the infectious plasmodial stage delivered into the host skin during a mosquito bite, can elicit sterile immunity to malaria. $\mathrm{CD}^{+} \mathrm{T}$ cells seem to play an essential role in this protective immunity, since their depletion consistently abolishes sterilizing protection in several experimental models. So far, only a few parasite antigens are known to induce $\mathrm{CD}^{+} \mathrm{T}$ cell-dependent protection, but none of them can reach the levels of protection afforded by live attenuated parasites. Systematic attempts to identify novel antigens associated with this efficient cellular protection were so far unsuccessful. In addition, the precise mechanisms involved in the recognition and elimination of parasitized hepatocytes in vivo by $\mathrm{CD} 8^{+} \mathrm{T}$ cells still remain obscure. Recently, it has been shown that specific effector $\mathrm{CD} 8^{+} \mathrm{T}$ cells, after recognition of parasitized hepatocytes, recruit specific and non-specific activated $\mathrm{CD} 8^{+} \mathrm{T}$ cells to the site of infection, resulting in the formation of cellular clusters around and in the further elimination of intracellular parasites. The significance of this finding is discussed in the perspective of a general mechanism of antigen-dependent focalized inflammation and its consequences for the elimination of malaria liver stages.

Keywords: CD8 ${ }^{+}$T cells, inflammatory infiltrate, cooperative behavior, in vivo imaging, Plasmodium

\section{THE PRE-ERYTHROCYTIC PHASE OF MALARIA INFECTION}

Malaria is a mosquito borne disease caused by Plasmodium spp. parasites. Despite advances in control and prevention measures, malaria still kills > 600,000 people annually and no effective licensed vaccine is available so far (www.who.int/malaria/en). The disease is a consequence of repeated cycles of parasite invasion and replication inside red blood cells (RBC). However, before infecting the blood and causing the disease, the parasite must pass through a silent and asymptomatic pre-erythrocytic (PE) phase. In mammals, the PE phase starts with the inoculation of sporozoites into the extravascular regions of the host skin during a mosquito bite. Some of these highly motile stages get access to the blood circulation and home to the liver, where they traverse several hepatic cells before invading and developing, as liver stages, inside hepatocytes. One infected hepatocyte generates thousands of RBC-infective stages in 2 to $\sim 10$ days depending on the species. Finally, the PE phase finishes with the release of these invasive stages into the blood circulation (Ménard et al., 2013).

In contrast to the symptomatic erythrocytic phase of infection, which can reach the magnitude of $\sim 10^{12}$ circulating infected RBCs in hyperparasitemic adults (World Health Organization [WHO], 1990), the asymptomatic PE stages represent the smallest parasite burden ( $1 \sim 1000$ sporozoites and liver stages) inside the mammalian host (Medica and Sinnis, 2005). Consequently, these stages are considered as ideal targets for vaccine intervention, since early elimination of this minute population of extracellular sporozoites and intracellular liver stages could strategically block infection before pathogenesis and transmission of parasites to mosquitoes. Most importantly, immunizations using live sporozoites, which are blocked during hepatic development as consequence of irradiation (Nussenzweig et al., 1967), genetic modification (Mueller et al., 2005) or drugs (Friesen and Matuschewski, 2011), confer sterile protection against sporozoite re-infection in several experimental models, as well as in humans (Seder et al., 2013).

\section{THE PUZZLE OF LIVER STAGE KILLING BY CD8+T CELLS}

Although there is evidence that antibodies and $\mathrm{CD}^{+} \mathrm{T}$ cells contribute to the protection induced by live irradiated sporozoites (Schofield et al., 1987; Tsuji et al., 1990; Rodrigues et al., 1993; Doolan and Hoffman, 2000), $\mathrm{CD}^{+} \mathrm{T}$ cells seem to be the major players of this sterilizing immunity since in almost all tested rodent (Schofield et al., 1987; Doolan and Hoffman, 2000; Schmidt et al., 2010) and primate (Weiss and Jiang, 2012) models, sterile protection is abolished when $\mathrm{CD} 8^{+} \mathrm{T}$ cells are depleted before sporozoite challenge. Accordingly, the transfer of parasitespecific $\mathrm{CD}^{+} \mathrm{T}$ cells can also protect mice from sporozoite infection (Romero et al., 1989; Weiss et al., 1992).

This protective cellular response is associated with a high number of specific $\mathrm{CD}^{+} \mathrm{T}$ cells circulating in the peripheral blood of protected mice, ranging from $\sim 5$ to $60 \%$ of total circulating $\mathrm{CD}^{+}$T cells (Van Braeckel-Budimir and Harty, 2014). Similarly, adoptive transfer of $\sim 10^{7}$ activated specific $\mathrm{CD} 8^{+} \mathrm{T}$ cells, which totalize $\sim 26$ to $60 \%$ of $\mathrm{CD}^{+} \mathrm{T}$ cells circulating in the blood, is 
required to sterilize the infection in the liver, while the transfer of $10^{6} \mathrm{CD}^{+} \mathrm{T}$ cells, which represents $\sim 3 \%$ of $\mathrm{CD}^{+} \mathrm{T}$ cells circulating in the blood, is not enough to completely protect mice against sporozoite challenge (Kimura et al., 2013). In addition, interactions between $\mathrm{CD} 8^{+} \mathrm{T}$ cells and infected hepatocytes could not be observed after adoptive transfer of $10^{6}$ primed CD8 ${ }^{+}$ $\mathrm{T}$ cells to infected mice (Cabrera et al., 2013), suggesting that the recognition of infected hepatocytes is dependent on high numbers of specific $\mathrm{CD} 8^{+} \mathrm{T}$ cells. In humans, however, the levels of $\mathrm{CD}^{+} \mathrm{T}$ cells correlated with protection seem to be much lower than in rodents (Ewer et al., 2013). Protective activity is dependent not only on the quantity, but also on the quality of $\mathrm{CD}^{+} \mathrm{T}$ cells. For example, high expression levels of cell adhesion molecules such as CD44 and VLA-4 are correlated with the in vivo anti-parasite activity of $\mathrm{CD}^{+} \mathrm{T}$ cells, but not with their in vitro cytotoxic activity (Rodrigues et al., 1992). These molecules have been implicated in homotypic and heterotypic adhesion of lymphocytes, in the trafficking of T cells to inflamed site (Nandi et al., 2004), and could play an important role in the clustering of $\mathrm{T}$ cells at the site of infection (next sections).

Very little is known about the nature of protective parasite epitopes presented on the surface of infected hepatocytes by class I major histocompatibility complex molecules (MHC I). In rodent models, protective MHC I-restricted epitopes were described in the circumsporozoite protein (CSP, Romero et al., 1989; Weiss et al., 1992; Rodrigues et al., 1994; Schmidt et al., 2008) and in the thrombospondin-related anonymous protein (TRAP, Hafalla et al., 2013). Both CSP and TRAP are membrane proteins expressed mainly in sporozoites. In humans, immunization using adjuvanted, truncated CSP induced only partial protection without a detectable specific $\mathrm{CD}^{+} \mathrm{T}$ cell response (Moorthy and Ballou, 2009). Immunization using TRAP delivered by viral vectors, which elicit robust T-cell responses, induced also a partial protection which was correlated with the frequency of monofunctional interferon gamma (IFN $\gamma)$-producing $\mathrm{CD}^{+}$ T cells (Ewer et al., 2013). Intriguingly, several attempts to identify new epitopes targeted by $\mathrm{CD}^{+} \mathrm{T}$ cells among thousands of profiled peptides, mini-genes or genes covering hundreds of parasite proteins, have revealed only a few new PE candidate antigens, but none of them induced protection against sporozoite infection (Mishra et al., 2011; Murphy et al., 2013; Hafalla et al., 2013). Whether the difficulty to unravel new protective epitopes is a consequence of the method of screening, which relies on the secretion of IFN $\gamma$ by $\mathrm{CD}^{+}{ }^{+} \mathrm{T}$ cells detected by ELISPOT, or of immunization, which may not reach the critical $\mathrm{CD}^{+} \mathrm{T}$ cell threshold necessary for protection, remains to be determined.

Given the scarcity of protective CD8 epitopes, another convenient way to study $\mathrm{CD} 8^{+} \mathrm{T}$ cell responses against infected hepatocytes is to use the epitope of ovalbumin (OVA) fused to endogenous and exogenous antigens expressed in malaria PE stages (Cockburn et al., 2011; Kimura et al., 2013; Montagna et al., 2014). This strategy showed that membrane, cytoplasmic and tubulovesicular network exported proteins can harbor epitopes that are presented on the surface of infected hepatocytes, leading to the parasite elimination by MHC I-restricted $\left(\mathrm{H}-2 \mathrm{~K}^{\mathrm{b}}\right)$, OVA-specific $\mathrm{CD} 8^{+} \mathrm{T}$ cells (OT-I cells). Although antigen-presentation is dependent on the transporter associated with antigen processing (TAP; Cockburn et al., 2011; Kimura et al., 2013), which translocates peptides from the cytosol into the endoplasmic reticulum where they are loaded onto MHC I molecules, the mechanism by which these membrane, cytoplasmic and exported parasite antigens cross the parasitophorous vacuole membrane and reach the host cell cytoplasm is still controversial and unclear (Singh et al., 2007; Cockburn et al., 2011; Montagna et al., 2014).

The mechanisms by which $\mathrm{CD} 8^{+} \mathrm{T}$ cells eliminate liver stages are also puzzling. Systemic depletion of IFN $\gamma$ consistently abolishes the sterile protection induced by irradiated sporozoites in rodent models (Schofield et al., 1987; Doolan and Hoffman, 2000). However, activated IFN $\gamma^{-1-} \mathrm{CD}^{+} \mathrm{T}$ cells harboring transgenic T-cell receptors (TCRs), which can recognize specific cognate epitopes presented on the surface of infected hepatocytes, are still capable of controlling infection as their IFN $\gamma$-proficient counterparts (Chakravarty et al., 2008; Kimura et al., 2013). The same is observed for FasL and/or perforin knockout CD8 ${ }^{+} \mathrm{T}$ cells (Morrot and Zavala, 2004; Kimura et al., 2013). Finally, sterile protection is only lost in a proportion of animals injected with double IFN $\gamma$ and perforin knockout $\mathrm{CD} 8^{+} \mathrm{T}$ cells (Kimura et al., 2013). Altogether these loss-of-function studies depict a scenario where the elimination of liver stages by specific $\mathrm{CD}^{+} \mathrm{T}$ cells seems to be a complex process involving several and redundant effector molecules and probably other IFN $\gamma$-producing immune cells.

\section{CD8 ${ }^{+}$T CELL-DEPENDENT INFLAMMATORY FOCI AND THE DEATH OF LIVER STAGES}

While molecular mechanisms underlying the elimination of liver stages by $\mathrm{CD}^{+} \mathrm{T}$ cells are still unclear, the cellular events leading to the death of these hepatic parasites are only slowly being revealed. In 1989, multiple inflammatory foci containing numer-

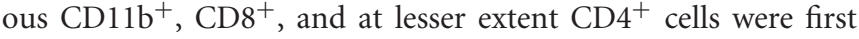
observed in the liver of BALB/c mice immunized with $P$. berghei $(\mathrm{Pb})$ irradiated sporozoites, $43 \mathrm{~h}$ after challenge with normal sporozoites. Although no parasites could be observed in association with these infiltrates, the formation of these cellular foci was dependent on the presence of CD8 ${ }^{+}$T cells (Hoffman et al., 1989).

Several years later, DNA in situ hybridization revealed remnants of $\mathrm{Pb}$ parasites in close association with cellular infiltrates in the liver of rats immunized with irradiated sporozoites and challenged with normal sporozoites (Scheller et al., 1997). The number of infiltrates increased after $24 \mathrm{~h}$ post-challenge and coincided with the decrease in the number of liver stages in the immunized rats. $\mathrm{CD}^{+}$and $\mathrm{CD}^{+} \mathrm{T}$ cells were also identified in these infiltrates. The number of $\mathrm{CD}^{+}$cells was maintained constant at $31 \mathrm{~h}$ and $44 \mathrm{~h}$ post-infection, while the number of $\mathrm{CD}^{+} \mathrm{T}$ cells was four and sixfold superior to those of $\mathrm{CD} 4^{+} \mathrm{T}$ cells at these respective time points.

Notably, systemic inhibition of nitric oxide (NO) production by aminoguanidine reduced the number of inflammatory foci after $24 \mathrm{~h}$ post-infection with a clear diminution of the number of $\mathrm{CD}^{+}$lymphocytes in the focal infiltrates (Scheller et al., 1997). This treatment also abolished the elimination of liver stages in the immunized animals indicating that the production of $\mathrm{NO}$ is critical for the accumulation of $\mathrm{CD}^{+} \mathrm{T}$ cells, which 
are necessary for the parasite elimination. However, the source of inducible NO synthase in the liver of immunized rats challenged with sporozoites seems to be restricted to infected hepatocytes (Klotz et al., 1995). Since NO produced by infected hepatocytes is involved in the elimination of parasites in vitro in the absence of T cells (Nussler et al., 1993; Mellouk et al., 1994), it is not possible to distinguish if aminoguanidine abolished elimination of liver stages in the immunized animal by the direct inhibition of NO anti-plasmodial activity, by the inhibition of inflammatory responses that induce the accumulation of $\mathrm{CD}^{+} \mathrm{T}$ cells around the infected hepatocytes, or both. Studies using specific $\mathrm{CD}^{+}$ $\mathrm{T}$ lymphocytes or liver cells that are deficient in the inducible synthesis of NO could precise the role of this molecule in the killing of liver stages.

\section{ANTIGEN-DRIVEN INFLAMMATORY FOCI}

Recently, in vivo imaging revealed $\mathrm{CD} 8^{+} \mathrm{T}$ cell infiltrates in close association with infected hepatocytes in $\mathrm{BALB} / \mathrm{c}$ mice immunized with irradiated P. yoelii (Py) sporozoites (Cockburn et al., 2013). The use of fluorescent $\mathrm{CD}^{+}{ }^{+} \mathrm{T}$ cells harboring transgenic TCRs, specific for epitopes expressed by the parasite and presented by MHC I molecules on the surface of infected hepatocytes, also showed that cluster formation mediated by $\mathrm{CD} 8^{+} \mathrm{T}$ cells is antigen specific. Activated $\mathrm{CD} 8^{+} \mathrm{T}$ cells, which recognize specifically a $P y$ CSP-epitope, clustered around and eliminated $P y$ infected hepatocytes. Conversely activated OT-I cells did not cluster or eliminate $P y$ and $P b$ infected hepatocytes, but readily clustered around and eliminated hepatocytes infected with $\mathrm{Pb}$ expressing the CD8 epitope of OVA (Cockburn et al., 2013; Kimura et al., 2013). The frequency distribution of $P y C S P-s p e c i f i c ~ C D 8^{+} \mathrm{T}$ cells around infected hepatocytes fitted a mathematical model where the recruitment of $\mathrm{T}$ cells was density-dependent, indicating that activated $\mathrm{CD}^{+} \mathrm{T}$ cells were attracted to a cluster. The close apposition of $\mathrm{CD}^{+} \mathrm{T}$ cells with infected hepatocytes suggests that this first step of specific recognition and recruitment is initiated by the direct contact between these two cells (Figure 1A). Hepatocytes traversed by sporozoites are also thought to present antigens to $\mathrm{CD}^{+} \mathrm{T}$ cells. Although traversed hepatocytes do not alter the elimination of infected cells by $\mathrm{CD}^{+} \mathrm{T}$ cells in vitro (Bongfen et al., 2007), the role of liver cells traversed by sporozoites (Mota et al., 2001; Tavares et al., 2013a,b) located adjacent to infected hepatocytes cannot be formally excluded in the process of initiation and formation of these cellular inflammatory foci (Figure 1B). This capacity of $\mathrm{CD} 8^{+} \mathrm{T}$ cells to recognize a cognate antigen and recruit other $\mathrm{CD}^{+}{ }^{+} \mathrm{T}$ cells to the site of infection seems to be a general and novel function of $\mathrm{CD}^{+} \mathrm{T}$ cells, as reported recently in a model of mouse reproductive tract infection by the lymphocytic choriomeningitis virus (Schenkel et al., 2013).

Surprisingly, when activated $P y C S P$-specific and non-specific $\mathrm{CD}^{+}$T cells were transferred together in mice infected with $P y$ sporozoites, non-specific $\mathrm{CD}^{+} \mathrm{T}$ cells, which usually did not cluster around $P y$ infected hepatocytes, modified their behavior and were recruited together with PyCSP-specific CD8 ${ }^{+} \mathrm{T}$ cells to the site of infection (Cockburn et al., 2013). In a tumor model, activated OT-I cells were also responsible for the deep infiltration and accumulation of activated non-specific $\mathrm{T}$ cells in OVA-expressing EL4 tumors (Boissonnas et al., 2007), indicating

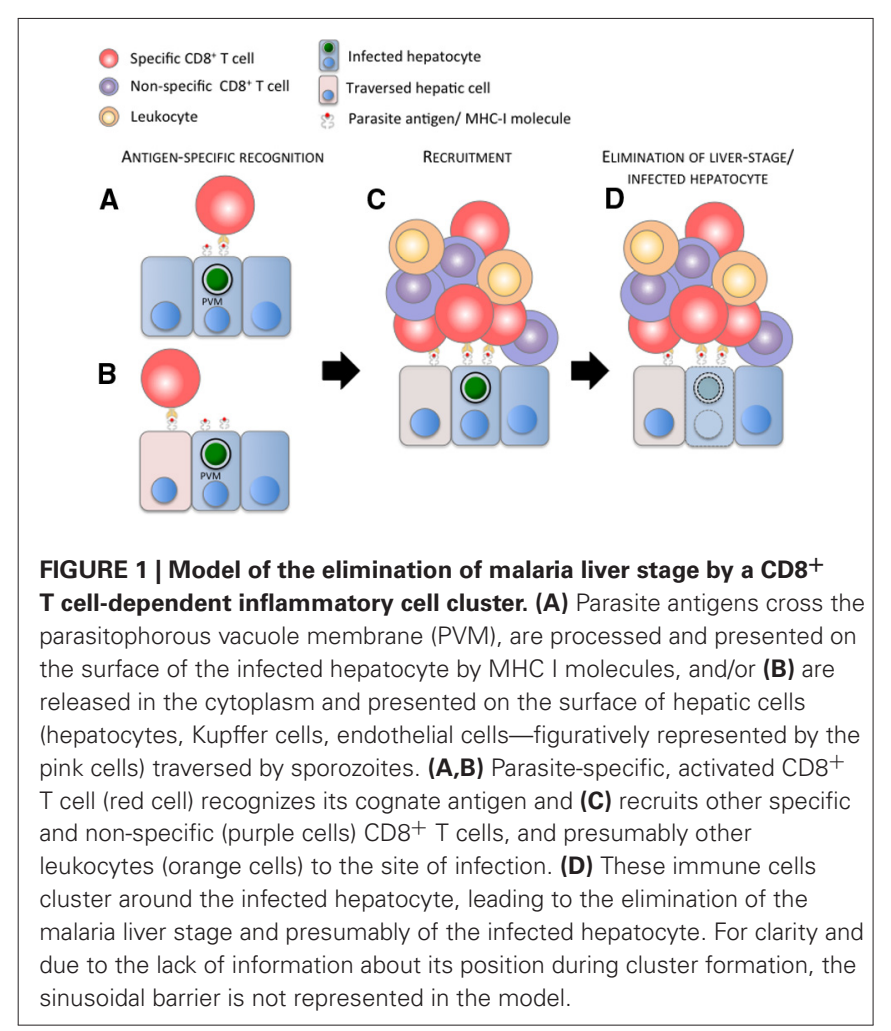

that $\mathrm{CD}^{+} \mathrm{T}$ cells not only exert a direct cytotoxic activity on target cells, but can also orchestrate a focal inflammatory response by the recognition of a specific antigen and further recruitment of specific and non-specific T cells to the site of infection or tumor growth. This inflammatory role is in agreement with the recent observation that $\mathrm{CD} 8^{+} \mathrm{T}$ cells express a burst of inflammatory cytokines immediately after cognate antigen stimulation recruiting diverse cellular types involved in inflammatory reactions (Sung et al., 2013).

\section{MULTIPLICITY OF PARASITE DEATH PHENOTYPES}

Dynamic imaging revealed how clusters of activated $\mathrm{CD} 8^{+} \mathrm{T}$ cells eliminate liver stages in vivo (Cockburn et al., 2013; Kimura et al., 2013). The utilization of a vitality index (VI) based on the fluorescence intensity of GFP-expressing liver stages permitted the monitoring of parasite viability/death over hours of observation after the transfer of activated and specific $\mathrm{CD} 8^{+} \mathrm{T}$ cells. Strikingly, killing of liver stages was a lasting process, which on average occurred after several hours of association between $\mathrm{CD}^{+} \mathrm{T}$ cells and infected hepatocytes. In addition, the kinetics of the VI of fluorescent parasites allowed the discrimination of at least three distinct death phenotypes (DPs) associated with the presence of activated $\mathrm{CD}^{+} \mathrm{T}$ cells. An abrupt decrease in the parasite VI followed by the diffusion of a weak GFP signal through the host cell cytoplasm characterized the first DP. The second DP was characterized by a slow decrease in the VI over hours of interaction. The blebbing of the infected hepatocyte with the release of parasite material into the sinusoids characterized the third DP. All these distinct DPs suggest again that parasite elimination could rely on multiple and redundant mechanisms of killing. 
A better understanding of these killing mechanisms might be achieved using functional in vivo imaging. This strategy is a double approach that combines the quantitative imaging of mutant cells with the imaging of non-mutant cells using specific fluorescent reporters to investigate function (Tavares et al., 2013a). For example, the correlation between the ablation of a cytotoxic effector molecule in protective $\mathrm{CD}^{+} \mathrm{T}$ cells and the loss of a given DP could indicate a causal relation between these two variables. Complementary, the use of fluorescent markers that report the level of expression of cytotoxic molecules (Croxford and Buch, 2011; Mouchacca et al., 2013) could be used to discriminate different populations of protective $\mathrm{CD} 8^{+} \mathrm{T}$ cells and their relationship with the DPs could be assessed by in vivo imaging. The latter approach could also reveal what is the activation phenotype of $\mathrm{CD}^{+} \mathrm{T}$ cells associated with efficient homing to the liver, recognition of infected hepatocytes, clustering formation and killing of liver stages.

\section{CLUSTERING OF CELLS FACILITATES ELIMINATION OF LIVER STAGES}

Qualitatively a few $\mathrm{CD}^{+} \mathrm{T}$ cells are sufficient to rapidly eliminate a liver stage in vitro (Trimnell et al., 2009), however, the killing process in vivo seems to be much longer and complex, involving multiple cells (Cockburn et al., 2013). Whether these differences are due to intrinsic characteristics of $\mathrm{CD}^{+} \mathrm{T}$ cells used in these studies or are a consequence of limitations imposed by an in vitro system is not yet determined. The liver possesses an immune-privileged environment, which confers a relatively high resistance against $\mathrm{CD}^{+} \mathrm{T}$ cell responses (Pircher et al., 2006). This fact could explain the long time that these cells require to eliminate liver stages in vivo. Cell clustering triggered by antigenspecific $\mathrm{CD}^{+} \mathrm{T}$ cells might possibly facilitate the process of parasite killing by augmenting the local concentration of protective cellular and molecular effectors. To test this hypothesis, cluster formation was inhibited by targeting chemokine signaling. Chemokines act on $\mathrm{T}$ cells via G-Protein Coupled Receptors (GPCRs) signaling. Pertussis toxin (PTx) was used to inhibit GPCR signaling through the ADP-ribosylation and uncoupling of G-Proteins (Cotton and Claing, 2009). Activated PyCSP-specific $\mathrm{CD}^{+} \mathrm{T}$ cells treated with PTx had an impaired capacity to cluster around and eliminate infected hepatocytes, while maintaining their capacity to kill target cells and secrete cytokines in vitro, as well as, to home to the liver in vivo (Cockburn et al., 2013). Although this pharmacological approach indicates that the clustering of cells triggered by $P y C S P-s p e c i f i c ~ C D 8{ }^{+} \mathrm{T}$ cells around infected hepatocytes facilitates the elimination of malaria liver stages, the identification of the chemokine(s) involved in the recruitment of cells to a cluster is still missing. The discovery of these molecules will permit a precise assessment, e.g., using knockout animals, of the role of cell clustering in the elimination of malaria liver stages.

\section{CONCLUDING REMARKS AND PERSPECTIVES}

Altogether these data suggest that $\mathrm{CD}^{+} \mathrm{T}$ cell-dependent elimination of liver stages is a complex and cooperative process involving multiple cells and effector molecules. An elevated number of $\mathrm{CD}^{+} \mathrm{T}$ cells with a proper binding phenotype seem to be required for finding and eliminating the scarce population of infected hepatocytes in the liver. Following antigen-specific recognition of the site of infection by activated $\mathrm{CD}^{+} \mathrm{T}$ cells, both specific and non-specific $\mathrm{CD}^{+} \mathrm{T}$ cells and likely other immune cells are recruited to the site of infection. Finally infected hepatocytes are cleared by these antigen-driven inflammatory foci, displaying a multiplicity of DPs. This mechanism of killing places $\mathrm{CD}^{+} \mathrm{T}$ cells as an essential linker between a specific adaptive immune response, which starts with the recognition of an infected cell, and a non-specific immune response, characterized by the recruitment of inflammatory cells to the site of infection and ensuing elimination of liver stages (Figure 1). This multi-cellular cooperative model of killing can also incorporate the relative importance of other cellular types, like CD4 ${ }^{+} \mathrm{T}$ cells and other IFN $\gamma$-producing cells, in the foci composition and protection. It may also explain the general dependence on IFN $\gamma$ for sterile immunity but the dispensable role of this cytokine for protection induced by parasite-specific IFN $\gamma^{-1-}$ $\mathrm{CD}^{+} \mathrm{T}$ cells.

Important topics related to the formation, composition and killing efficacy of these $\mathrm{CD}^{+} \mathrm{T}$ cell-dependent inflammatory foci are still unclear and need further investigation. One of these topics is the identification of novel protective CD8 epitopes presented on the surface of hepatocytes (Crabb et al., 2012) and the verification of their concerted action with other known protective epitopes, such as those described in CSP and TRAP. This approach could reveal a possible synergistic, additive, neutral or antagonistic effect on cluster formation and protection. Another important subject to address is the contribution of $\mathrm{CD}^{+} \mathrm{T}$ cells, which cannot recognize infected hepatocytes, but are specifically activated in the lymph node that drains the bite site, for example, by mosquito saliva or sporozoite antigens (Chakravarty et al., 2007), in foci formation and elimination of liver stages. Once it is determined that the recruitment of these activated $\mathrm{CD}^{+} \mathrm{T}$ cells to infected hepatocytes can improve the killing of liver stages, a vaccination strategy using protective epitopes, presented by infected hepatocytes, and inflammatory epitopes, which might improve killing by focal inflammation, could be envisaged and tested. Similarly the role of non-specific innate immune cells in cluster formation and killing activity is also an open question. It is well documented that inflammatory infiltrates are associated with the natural resistance of naive rodents to hepatic infection (Khan and Vanderberg, 1991), but their role in immunized animals is not known. In addition, depletion studies using multiple doses of anti-asialo GM1 antibodies partially abrogated protection induced by irradiated sporozoites in several mouse strains (Doolan and Hoffman, 2000). This treatment is known to efficiently deplete NK cells and basophils, and despite the expression of asialo GM1 on subpopulations of NKT, CD8 ${ }^{+}$ $\mathrm{T}$ and $\gamma \delta \mathrm{T}$ cells, no significant depletion was observed after a single dose of anti-asialo GM1 antibodies in C57BL/6 mice (Nishikado et al., 2011). This suggests that NK cells, basophils and other innate immune cells could also participate in the focal inflammation orchestrated by specific $\mathrm{CD} 8^{+} \mathrm{T}$ cells. Finally the unraveling of the molecular determinants of highly protective $\mathrm{CD}^{+} \mathrm{T}$ cells is crucial for defining the type of effector cells a vaccine should generate. All this information could be 
very useful for the design of an immunization strategy aiming at the efficient elimination of malaria liver stages mediated by $\mathrm{CD} 8^{+} \mathrm{T}$ cells.

\section{ACKNOWLEDGMENTS}

We would like to thank our collaborators, Institut Pasteur and French National Research Agency_ANR PlasmoPEP (RA), Japan Society for the Promotion of Science (JSPS) KAKENHI grant number 25113717 (KY) and Program for Nurturing Global Leaders in Tropical and Emerging Communicable diseases of Nagasaki University (GB) for the support, and Robert Menard for critically reading the manuscript. We also apologize for all colleagues whose work was not cited here due to space limitations or unawareness.

\section{REFERENCES}

Bongfen, S. E., Torgler, R., Romero., J. F., Renia. L., and Corradin, G. (2007). Plasmodium berghei-infected primary hepatocytes process and present the circumsporozoite protein to specific $\mathrm{CD}^{+} \mathrm{T}$ cells in vitro. J. Immunol. 178, 70547063. doi: 10.4049/jimmunol.178.11.7054

Boissonnas, A., Fetler, L., Zeelenberg., I. S., Hugues. S., and Amigorena, S. (2007). In vivo imaging of cytotoxic $\mathrm{T}$ cell infiltration and elimination of a solid tumor. J. Exp. Med. 204, 345-356. doi: 10.1084/jem.20061890

Cabrera, M., Pewe, L. L., Harty., J. T., and Frevert, U. (2013). In vivo CD8 ${ }^{+}$T cell dynamics in the liver of Plasmodium yoelii immunized and infected mice. PLoS ONE 8:e70842. doi: 10.1371/journal.pone.0070842

Chakravarty, S., Baldeviano, G. C., Overstreet, M. G., and Zavala, F. (2008). Effector $\mathrm{CD}^{+} \mathrm{T}$ lymphocytes against liver stages of Plasmodium yoelii do not require gamma interferon for antiparasite activity. Infect. Immun. 76, 3628-3631. doi: 10.1128/IAI.00471-08

Chakravarty, S., Cockburn, I. A., Kuk, S., Overstreet, M. G., Sacci, J. B., and Zavala, F. (2007). CD ${ }^{+}$T lymphocytes protective against malaria liver stages are primed in skin-draining lymph nodes. Nat. Med. 13, 1035-1041. doi: 10.1038/nm1628

Cockburn, I. A., Amino, R., Kelemen, R. K., Kuo, S. C., Tse, S. W., Radtke, A., et al. (2013). In vivo imaging of CD8+ T cell-mediated elimination of malaria liver stages. Proc. Natl. Acad. Sci. U.S.A. 110, 9090-9095. doi: 10.1073/pnas. 1303858110

Cockburn, I. A., Tse, S. W., Radtke, A. J., Srinivasan, P., Chen, Y. C., Sinnis, P., et al. (2011). Dendritic cells and hepatocytes use distinct pathways to process protective antigen from Plasmodium in vivo. PLoS Pathog. 7:e1001318. doi: 10.1371/ journal.ppat.1001318

Cotton, M., and Claing, A. (2009). G protein-coupled receptors stimulation and the control of cell migration. Cell. Signal. 21, 1045-1053. doi: 10.1016/j.cellsig. 2009.02.008

Crabb, B. S., Beeson, J. G., Amino, R., Ménard, R., Waters, A., Winzeler, E. A., et al. (2012). Perspectives: the missing pieces. Nature 484, S22-S23. doi: 10.1038/ $484 \mathrm{~S} 22 \mathrm{a}$

Croxford, A. L., and Buch, T. (2011). Cytokine reporter mice in immunological research: perspectives and lessons learned. Immunology 132, 1-8. doi: 10.1111/ j.1365-2567.2010.03372.x

Doolan, D. L., and Hoffman, S. L. (2000). The complexity of protective immunity against liver-stage malaria. J. Immunol. 165, 1453-1462. doi: 10.4049/jimmunol. 165.3.1453

Ewer, K. J., O’Hara, G. A., Duncan, C. J., Collins, K. A., Sheehy, S. H., ReyesSandoval, A., et al. (2013). Protective CD ${ }^{+}$T-cell immunity to human malaria induced by chimpanzee adenovirus-MVA immunisation. Nat. Commun. 4, 2836. doi: $10.1038 /$ ncomms 3836

Friesen, J., and Matuschewski, K. (2011). Comparative efficacy of pre-erythrocytic whole organism vaccine strategies against the malaria parasite. Vaccine 29, $7002-$ 7008. doi: 10.1016/j.vaccine.2011.07.034

Hafalla, J. C., Bauza, K., Friesen, J., Gonzalez-Aseguinolaza, G., Hill, A. V., and Matuschewski, K. (2013). Identification of targets of $\mathrm{CD}^{+} \mathrm{T}$ cell responses to malaria liver stages by genome-wide epitope profiling. PLoS Pathog. 9:e1003303. doi: 10.1371/journal.ppat.1003303

Hoffman, S. L., Isenbarger, D., Long, G. W., Sedegah, M., Szarfman, A., Waters, L., et al. (1989). Sporozoite vaccine induces genetically restricted
T cell elimination of malaria from hepatocytes. Science 244, 1078-1081. doi: 10.1126/science. 2524877

Khan, Z. M., and Vanderberg, J. P. (1991). Role of host cellular response in differential susceptibility of nonimmunized BALB/c mice to Plasmodium berghei and Plasmodium yoelii sporozoites. Infect. Immun. 59, 2529-2534.

Kimura, K., Kimura, D., Matsushima, Y., Miyakoda, M., Honma, K., Yuda, M., et al. (2013). CD8 ${ }^{+} \mathrm{T}$ cells specific for a malaria cytoplasmic antigen form clusters around infected hepatocytes and are protective at the liver stage of infection. Infect. Immun. 81, 3825-3834. doi: 10.1128/IAI.00570-13

Klotz, F. W., Scheller, L. F., Seguin, M. C., Kumar, N., Marletta, M. A., Green, S. J., et al. (1995). Co-localization of inducible-nitric oxide synthase and Plasmodium berghei in hepatocytes from rats immunized with irradiated sporozoites. J. Immunol. 154, 3391-3395.

Medica, D. L., and Sinnis, P. (2005). Quantitative dynamics of Plasmodium yoelii sporozoite transmission by infected anopheline mosquitoes. Infect. Immun. 73, 4363-4369. doi: 10.1128/IAI.73.7.4363-4369.2005

Mellouk, S., Hoffman, S. L., Liu, Z. Z., de la Vega, P., Billiar, T. R., and Nussler, A. K. (1994). Nitric oxide-mediated antiplasmodial activity in human and murine hepatocytes induced by gamma interferon and the parasite itself: enhancement by exogenous tetrahydrobiopterin. Infect. Immun. 62, 4043-4046.

Ménard, R., Tavares, J., Cockburn, I., Markus, M., Zavala, F., and Amino, R. (2013). Looking under the skin: the first steps in malarial infection and immunity. Nat. Rev. Microbiol. 11, 701-712. doi: 10.1038/nrmicro3111

Mishra, S., Rai, U., Shiratsuchi, T., Li, X., Vanloubbeeck, Y., Cohen, J., et al. (2011). Identification of non-CSP antigens bearing CD8 epitopes in mice immunized with irradiated sporozoites. Vaccine 29, 7335-7342. doi: 10.1016/ j.vaccine.2011.07.081

Montagna, G. N., Beigier-Bompadre, M., Becker, M., Kroczek, R. A., Kaufmann, S. H., and Matuschewski, K. (2014). Antigen export during liver infection of the malaria parasite augments protective immunity. mBio 5, e01321-e01314. doi: 10.1128/mBio.01321-14

Moorthy, V. S., and Ballou, W. R. (2009). Immunological mechanisms underlying protection mediated by RTS,S: a review of the available data. Malar J. 8, 312. doi: 10.1186/1475-2875-8-312

Morrot, A., and Zavala, F. (2004). Effector and memory CD8 ${ }^{+} \mathrm{T}$ cells as seen in immunity to malaria. Immunol. Rev. 201, 291-303. doi: 10.1111/j.01052896.2004.00175.x

Mota, M. M., Pradel, G., Vanderberg, J. P., Hafalla, J. C., Frevert, U., Nussenzweig, R. S., et al. (2001). Migration of Plasmodium sporozoites through cells before infection. Science 291, 141-144. doi: 10.1126/science.291.5501.141

Mouchacca, P., Schmitt-Verhulst, A. M., and Boyer, C. (2013). Visualization of cytolytic $\mathrm{T}$ cell differentiation and granule exocytosis with $\mathrm{T}$ cells from mice expressing active fluorescent granzyme B. PLoS ONE 8:e67239. doi: 10.1371/ journal.pone.0067239

Mueller, A. K., Labaied, M., Kappe, S. H., and Matuschewski, K. (2005). Genetically modified Plasmodium parasites as a protective experimental malaria vaccine. Nature 433, 164-167. doi: 10.1038/nature03188

Murphy, S. C., Kas, A., Stone, B. C., and Bevan, M. J. (2013). A T-cell response to a liver-stage Plasmodium antigen is not boosted by repeated sporozoite immunizations. Proc. Natl. Acad. Sci. U.S.A. 110, 6055-6060. doi: 10.1073/pnas. 1303834110

Nandi, A., Estess, P., and Siegelman, M. (2004). Bimolecular complex between rolling and firm adhesion receptors required for cell arrest; CD44 association with VLA-4 in T cell extravasation. Immunity 20, 455-465. doi: 10.1016/S10747613(04)00077-9

Nishikado, H., Mukai, K., Kawano, Y., Minegishi, Y., and Karasuyama, H. (2011). NK cell-depleting anti-asialo GM1 antibody exhibits a lethal off-target effect on basophils in vivo. J. Immunol. 186, 5766-5771. doi: 10.4049/jimmunol. 1100370

Nussenzweig, R. S., Vanderberg, J., Most, H., and Orton, C. (1967). Protective immunity produced by the injection of x-irradiated sporozoites of Plasmodium berghei. Nature 216, 160-162. doi: 10.1038/216160a0

Nussler, A. K., Rénia, L., Pasquetto, V., Miltgen, F., Matile, H., and Mazier, D. (1993). In vivo induction of the nitric oxide pathway in hepatocytes after injection with irradiated malaria sporozoites, malaria blood parasites or adjuvants. Eur. J. Immunol. 23, 882-887. doi: 10.1002/eji.1830230417

Pircher, H., Akira, S., Hengartner, H., and Zinkenagel, R. M. (2006). Immunoprivileged status of the liver is controlled by Toll-like receptor 3 signaling. J. Clin. Invest. 116, 2456-2463. doi: 10.1172/JCI28349 
Rodrigues, M., Li, S., Murata, K., Rodriguez, D., Rodriguez, J. R., Bacik, I., et al. (1994). Influenza and vaccinia viruses expressing malaria $\mathrm{CD}^{+} \mathrm{T}$ and $\mathrm{B}$ cell epitopes. Comparison of their immunogenicity and capacity to induce protective immunity. J. Immunol. 153, 4636-4648.

Rodrigues, M., Nussenzweig, R. S., Romero, P., and Zavala, F. (1992). The in vivo cytotoxic activity of $\mathrm{CD}^{+} \mathrm{T}$ cell clones correlates with their levels of expression of adhesion molecules. J. Exp. Med. 175, 895-905. doi: 10.1084/jem.175.4.895

Rodrigues, M., Nussenzweig, R. S., and Zavala, F. (1993). The relative contribution of antibodies, $\mathrm{CD}^{+}$and $\mathrm{CD} 8^{+} \mathrm{T}$ cells to sporozoite-induced protection against malaria. Immunology. 80, 1-5.

Romero, P., Maryanski, J. L., Corradin, G., Nussenzweig, R. S., Nussenzweig, V., and Zavala, F. (1989). Cloned cytotoxic T cells recognize an epitope in the circumsporozoite protein and protect against malaria. Nature 341, 323-326. doi: $10.1038 / 341323 \mathrm{a} 0$

Scheller, L. F., Green, S. J., and Azad, A. F. (1997). Inhibition of nitric oxide interrupts the accumulation of $\mathrm{CD}^{+} \mathrm{T}$ cells surrounding Plasmodium bergheiinfected hepatocytes. Infect. Immun. 65, 3882-3888.

Schenkel, J. M., Fraser, K. A., Vezys, V., and Masopust, D. (2013). Sensing and alarm function of resident memory $\mathrm{CD}^{+}{ }^{+} \mathrm{T}$ cells. Nat. Immunol. 14, 509-513. doi: 10.1038/ni.2568

Schmidt, N. W., Butler, N. S., Badovinac, V. P., and Harty, J. T. (2010). Extreme CD8 $\mathrm{T}$ cell requirements for anti-malarial liver-stage immunity following immunization with radiation attenuated sporozoites. PLoS Pathog. 6:e1000998. doi: 10.1371/journal.ppat.1000998

Schmidt, N. W., Podyminogin, R. L., Butler, N. S., Badovinac, V. P., Tucker, B. J., Bahjat, K. S., et al. (2008). Memory CD8 T cell responses exceeding a large but definable threshold provide long-term immunity to malaria. Proc. Natl. Acad. Sci. U.S.A. 105, 14017-14022. doi: 10.1073/pnas.0805452105

Schofield, L., Villaquiran, J., Ferreira, A., Schellekens, H., Nussenzweig, R., and Nussenzweig, V. (1987). Gamma interferon, $\mathrm{CD}^{+} \mathrm{T}$ cells and antibodies required for immunity to malaria sporozoites. Nature 330, 664-666. doi: $10.1038 / 330664 \mathrm{a} 0$

Seder, R. A., Chang, L. J., Enama, M. E., Zephir, K. L., Sarwar, U. N., Gordon, I. J., et al. (2013). Protection against malaria by intravenous immunization with a nonreplicating sporozoite vaccine. Science 341, 1359-1365. doi: 10.1126/science. 1241800

Singh, A. P., Buscaglia, C. A., Wang, Q., Levay, A., Nussenzweig, D. R., Walker, J. R., et al. (2007). Plasmodium circumsporozoite protein promotes the development of the liver stages of the parasite. Cell 131, 492-504. doi: 10.1016/ j.cell.2007.09.013

Sung, H. C., Lemos, S., Ribeiro-Santos, P., Kozyrytska, K., Vasseur, F., Legrand, A., et al. (2013). Cognate antigen stimulation generates potent $\mathrm{CD}^{+}$inflammatory effector T cells. Front. Immunol. 4:452. doi: 10.3389/fimmu.2013. 00452
Tavares, J., Formaglio, P., Thiberge, S., Mordelet, E., Van Rooijen, N., Medvinsky, A., et al. (2013a). Role of host cell traversal by the malaria sporozoite during liver infection. J. Exp. Med. 210, 905-915. doi: 10.1084/jem.20121130

Tavares, J., Formaglio, P., Medvinsky, A., Ménard, R., and Amino, R. (2013b). Imaging sporozoite cell traversal in the liver of mice. Methods Mol. Biol. 923, 401-410. doi: 10.1007/978-1-62703-026-7_28

Trimnell, A., Takagi, A., Gupta, M., Richie, T. L., Kappe, S. H., and Wang, R. (2009). Genetically attenuated parasite vaccines induce contact-dependent $\mathrm{CD} 8^{+} \mathrm{T}$ cell killing of Plasmodium yoelii liver stage-infected hepatocytes. J. Immunol. 183, 5870-5878. doi: 10.4049/jimmunol.0900302

Tsuji, M., Romero, P., Nussenzweig, R. S., and Zavala, F. (1990). CD4 $4^{+}$cytolytic T cell clone confers protection against murine malaria. J. Exp. Med. 172, 13531357. doi: 10.1084/jem.172.5.1353

Van Braeckel-Budimir, N., and Harty, J. T. (2014). CD8 T-cell-mediated protection against liver-stage malaria: lessons from a mouse model. Front. Microbiol. 5:272. doi: 10.3389/fmicb.2014.00272

Weiss, W. R., Berzofsky, J. A., Houghten, R. A., Sedegah, M., Hollindale, M., and Hoffman, S. L. (1992). A T cell clone directed at the circumsporozoite protein which protects mice against both Plasmodium yoelii and Plasmodium berghei. J Immunol. 149, 2103-2109.

Weiss, W. R., and Jiang, C. G. (2012). Protective CD8 ${ }^{+}$T lymphocytes in primates immunized with malaria sporozoites. PLoS ONE 7:e31247. doi: 10.1371/journal.pone.0031247

World Health Organization [WHO]. (1990). Severe and complicated malaria. World Health Organization, division of control of tropical diseases. Trans. $R$. Soc. Trop. Med. Hyg. 84(Suppl. 2), S1-S65.

Conflict of Interest Statement: The authors declare that the research was conducted in the absence of any commercial or financial relationships that could be construed as a potential conflict of interest.

Received: 21 October 2014; accepted: 14 January 2015; published online: 04 February 2015.

Citation: Bayarsaikhan G, Akbari M, Yui K and Amino R (2015) Antigen-driven focal inflammatory death of malaria liver stages. Front. Microbiol. 6:47. doi: 10.3389/fmicb.2015.00047

This article was submitted to Microbial Immunology, a section of the journal Frontiers in Microbiology.

Copyright (c) 2015 Bayarsaikhan, Akbari, Yui and Amino. This is an open-access article distributed under the terms of the Creative Commons Attribution License (CC $B Y)$. The use, distribution or reproduction in other forums is permitted, provided the original author(s) or licensor are credited and that the original publication in this journal is cited, in accordance with accepted academic practice. No use, distribution or reproduction is permitted which does not comply with these terms. 